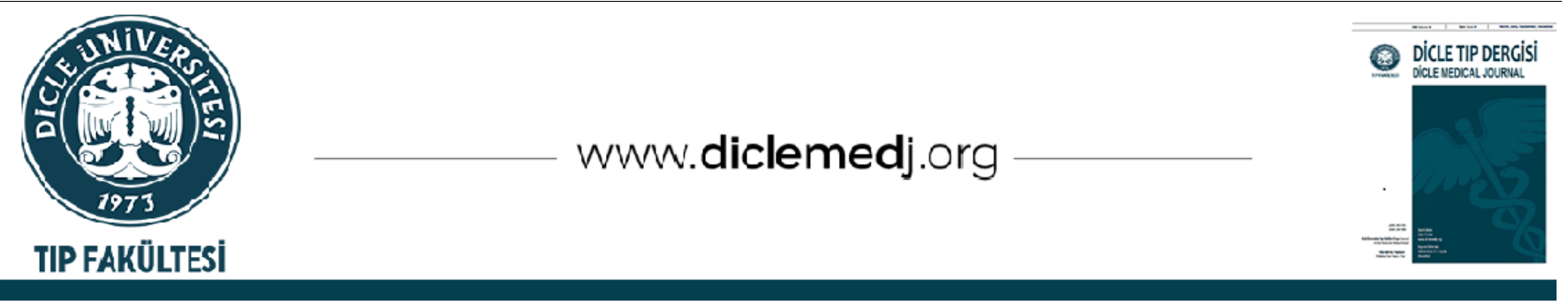

Original Article / Özgün Araştırma

\title{
Anticoagulant And Antiplatelet Medication Awareness of Preoperative Patients
}

\author{
Meltem Aktay Inal ${ }^{i}{ }_{1}$, Ozge Kurmus ${ }^{i{ }_{2}}$, Sedef Gulcin Ural ${ }^{(D)}$, Hatice Tolunay ${ }^{(D}{ }_{4}$ \\ 1 Seyhan State Hospital, Department of Anesthesiology and Reanimation, Adana, Turkey \\ 2 Ufuk University, Faculty of Medicine, Department of Cardiology, Ankara, Turkey \\ 3 Osmaniye State Hospital, Department of Anesthesiology and Reanimation, Adana-Turkey \\ 4 Gulhane Education and Research Hospital, Department of Cardiology, Ankara, Turkey
}

Received: 18.05.2020; Revised: 04.11.2020; Accepted: 24.11.2020

\begin{abstract}
Objective: To determine anticoagulant and anti-platelet medication awareness of peri-operative patients
\end{abstract}

Method: A questionnaire was applied to the 208 preoperative patients taking anticoagulants (AC) or anti-platelets (AP). The questionnaire included the questions about whether they were using any drug that thinners blood or prevents clots, indication and duration of drug use, whether they underwent an operation while using the drug, whether they knew that the drug should be discontinued in case of undergoing an operation and presence of a planned surgical procedure when commencing the drug.

Results: Mean age of the study population was $63.3 \pm 12.7$ years and $50.5 \%$ of the patients were male, $27.9 \%$ of the patients were illiterate, $39.4 \%$ of patients were not aware of using AC or AP and $12.5 \%$ of patients didn't know duration of AC or AP use. An operation had been planned before commencement of the drug in $9.1 \%$ of the patients. The incidence of undergoing a surgical procedure while using AC or AP was $18.8 \%$. While $23.1 \%$ were urgent, $76.9 \%$ were elective procedures. General anesthesia was applied in $41 \%$ of these patients. When the patients who were aware or unaware of $\mathrm{AC}$ or AP use were compared, mean age was younger and level of education was higher among the patients who were aware of using $\mathrm{AC}$ or $\mathrm{AP}(\mathrm{p}=0,018$ and $\mathrm{p}<0,001$ respectively). No difference was detected between the patients who were using old or new generation drugs with regard to awareness of drug use $(\mathrm{p}=0.113)$.

Conclusion: Patients who are taking AC or AP may have to undergo surgical procedures more than once while using these drugs. However, an important proportion (39.4 \%) of these patients was found to be unaware of using AC or AP.

Keywords: anticoagulant, anti-platelet, preoperative, awareness, survey

DOI: 10.5798/dicletip.850411

Correspondence / Yazıșma Adresi: Hatice Tolunay, Gulhane Education and Research Hospital, Department of Cardiology, Ankara, Turkey e-mail: drhaticearslan@gmail.com 


\section{Ameliyat Öncesi Değerlendirilen Hastaların Antikoagülan ve Antiplatelet İlaç Kullanım Farkındalı̆̆}

Öz

Amaç: Ameliyat planlanan hastaların kullanmakta oldukları antikoagulan ilaçlar (AKİ) ve antiplatelet ilaçlar (API) hakkındaki farkındalıklarını belirlemek çalışmanın amacıdır.

Yöntemler: AKİ veya APİ kullanan 208 hastaya preoperatif değerlendirmede anket uygulandı. Hastalara AKİ veya APİ kullanıp kullanmadığı, ilacın niçin başladığı, ne kadar süredir almakta olduğu, ilaç kullanımı sırasında cerrahi müdahale geçirip geçirmediği, geçirmesi gerekli durumda ilacın kesilmesini bilip bilmediği, ilaç başlanırken planlı bir operasyon hikayesi varlığı soruldu.

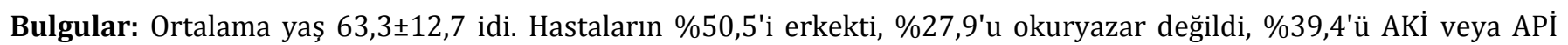
kullandığını bilmiyordu, \%12,5 'i ne kadar süredir kullandığını bilmiyordu. Hastaların \%9,1'inin ilaca başlanmadan önce planlanmış operasyonu mevcuttu. İlaç kullanırken operasyon geçirme oranı \%18,8 idi, bunların \%23,1'ini acil, \%76,9'unu elektif operasyonlar oluşturuyordu. \%41,0'na genel anestezi altında işlem uygulanmıştı. AKİ veya APİ kullandığının farkında olanlar ile farkında olmayanlar karşılaştırıldığında, farkında olanların yaş ortalamasının küçük ve okur yazarlık oranın fazla olduğu görüldü $(p=0,018, p<0,001)$. Yeni nesil ilaç kullananlarla eski nesil ilaç kullananlar karşılaştırıldığında ilaç kullanım farkındalığı açısından fark saptanmadı $(\mathrm{p}=0,113)$.

Sonuç: Antiplatelet veya antikoagulan ilaç kullanan hastalar birden fazla kez operasyon geçirmek durumunda kalabilir. Fakat bu hastaların \%39,4 gibi önemli bir kısmının kullandıkları antiplatelet veya antikoagulan ilacın farkında olmadığı saptanmıştır.

Anahtar kelimeler: antikoagülan, antiplatelet, preoperatif değerlendirme.

\section{INTRODUCTION}

Cardiovascular and cerebrovascular diseases are the most common causes of mortality ${ }^{1}$. Antiplatelet (AP) and anticoagulant (AC) medications are frequently used for prevention of these diseases ${ }^{2}$. While acetylsalicylic acid, clopidogrel and warfarin are still widely used, novel oral AP like ticagrelor and prasugrel, and novel AC like apixaban, rivaroxaban and dabigatran have also been introduced recently.

Time of discontinuation of drugs that can cause bleeding in pre-operative period and recommencement in post-operative period are quite important for anesthesia methods. Being aware of these drugs would enable to select the correct anesthesia method and to reveal the cause of the complications immediately particularly in the patients who would undergo urgent interventions.

The aim of present study is to evaluate anticoagulant and antiplatelet medication awareness in patients who would undergo an operation.

\section{METHODS}

Two hundred and eight out of 210 patients who were using oral AP and/or AC and consulted to Department of Anesthesia and Reanimation for pre-operative assessment between 1 June 2017 and 1 September 2017 were included in the study after ethics committee approval had been obtained from Mersin University and written informed consent had been obtained from the patients, 2 patients were excluded from the study although they had stated to use AP but they were not detected to use them. While AP medications included acetylsalicylic acid, clopidogrel, prasugrel and ticagrelor, AC included warfarin, apixaban, rivaroxaban and dabigatran. A questionnaire was applied to the patients who were using at least one of the abovementioned medications during preoperative evaluation.

\section{The questionnaire inquired the following;}


-whether they were using any AP or AC (Are you using a blood thinner/ platelet preventing medication?),

-the department which advised the medication and the indication of use

-duration of medication use and whether they were informed about how long they should use it

-presence of any planned operation when commencing the medication

-whether they underwent any surgical interventions when using the medication, the type of the operation (urgent or elective?) and the anesthesia method (general or regional?)

-stent type in the patients who were commenced the medication due to stent, whether they knew that the stent could be occluded in case of discontinuation of the drug.

The patients who could not complete the questionnaire, whose AC and /or AP use could not be verified through the medication boxes, their drug lists or through the information obtained from the relatives were not included in the study.

\section{Statistical Analysis}

Normality distribution of continuous variables was tested by using Kolmogorov-Smirnov test. Descriptive statistics were expressed as mean \pm standard deviation or median (minimummaximum), categorical variables were expressed as number and percent (\%). Significance of mean values between groups was evaluated by using Student's t-test. Significance of difference for continuous variables with normality distribution was analyzed with Mann Whitney u test. Categorical variables were evaluated with Pearson chisquare test. A p level of $<0,05$ was accepted as statistically significant.

\section{RESULTS}

A total of 208 patients were included in the study. Mean age of the patients was $63.3 \pm 12.7$ years, $50.5 \%$ of the patients were males, $49.5 \%$ of the patients were females and $27.9 \%$ of the patients were illiterate (Table 1). Acetylsalicylic acid was found to be the most commonly used $\mathrm{AP}$ and /or AC in all cases.

Table I: Socio-demographic characteristics of the cases

\begin{tabular}{|lc|}
\hline & $\mathbf{n = 2 0 8}$ \\
\hline Age (year)* & $63.3 \pm 12.7$ \\
\hline Age range (year)** & $22-99$ \\
\hline Gender $* * *$ & $105(50.5 \%)$ \\
\hline Male & $103(49.5 \%)$ \\
\hline Female & \\
\hline Education level ${ }^{* * *}$ & $58(27.9 \%)$ \\
\hline Illiterate & $24(11.5 \%)$ \\
\hline Literate & $65(31.3 \%)$ \\
\hline Elementary school & $35(16.8 \%)$ \\
\hline Intermediate school & $21(10.1 \%)$ \\
\hline High school & $5(2.4 \%)$ \\
\hline University & \\
\hline
\end{tabular}

${ }^{*}$ mean \pm standard deviation, ${ }^{* *}$ minimum-maximum value, ${ }^{* * *}$ number of the cases (\%)

Of the 208 patients, $39.4 \%$ were not aware of using AP and/or AC, 72 (34.6\%) answered the question "Are you using any blood thinner/clot preventing drugs?" as "I don't know", and 10 (4.8\%) as "No" (Table 2). An operation had been planned before starting the medication in 9.1\% of the patients. Ratio of undergoing an operation was $18.8 \%$ during the use of AP or AC. While $23.1 \%$ of these operations were urgent, 76.9\% were elective. General anesthesia was applied in $41.0 \%$ and regional anesthesia was applied in $59.0 \%$ (Table 2). The most common indication for AP and /or AC use was reported as coronary stent implantation followed by arrhythmia. Cardiology was found to be the 
department which started medications most commonly (70.2\%). Of the 208 patients, $12.5 \%$ did not know for how long they had been using $\mathrm{AP}$ and/or $\mathrm{AC}$, and $76.9 \%$ stated that they were not informed about how long they should continue the medication (Table 2). While only $15(21.4 \%)$ out of 70 patients who were started medication due to stent implantation knew the stent type, remaining 55 (78.6\%) did not know the stent type. More than half of the patients (58.6\%) did not know that the stent may be occluded in case of discontinuation of the AP drug.

Table II: Awareness of blood thinner medication use and the other clinical characteristics

\begin{tabular}{|c|c|}
\hline & $\mathrm{n}=\mathbf{2 0 8}$ \\
\hline \multicolumn{2}{|l|}{ Are you using blood thinner medications? } \\
\hline Yes & $126(60.6 \%)$ \\
\hline No & $10(4.8 \%)$ \\
\hline I don't know & $72(34.6 \%)$ \\
\hline Patients who do not know since when he/she has been using the medication & $26(12.5 \%)$ \\
\hline Duration of blood thinner medication use (year) & $2(0.08-20)$ \\
\hline $\begin{array}{l}\text { Patients who had been planned to undergo an elective operation before the beginning of the } \\
\text { medication }\end{array}$ & $19(9.1 \%)$ \\
\hline \multicolumn{2}{|l|}{ Department which has started the therapy } \\
\hline Neurology & $21(10.1 \%)$ \\
\hline Cardiology & $146(70.2 \%)$ \\
\hline Cardio-vascular surgery & $37(17.8 \%)$ \\
\hline Others & $4(1.9 \%)$ \\
\hline Patients who were informed about the overall duration of medication use & $48(23.1 \%)$ \\
\hline \multicolumn{2}{|l|}{ Indications for medication } \\
\hline Cerebrovascular event & $23(11.1 \%)$ \\
\hline Stenting & $70(33.7 \%)$ \\
\hline Arrhythmia & $64(30.8 \%)$ \\
\hline Peripheral vascular disease & $37(17.8 \%)$ \\
\hline Others & $45(21.6 \%)$ \\
\hline Unknown & $10(4.8 \%)$ \\
\hline Patients who undergo an operation in the course of drug use & $39(18.8 \%)$ \\
\hline \multicolumn{2}{|l|}{ Type of the operation } \\
\hline Urgent & $9(23.1 \%)$ \\
\hline Elective & $30(76.9 \%)$ \\
\hline \multicolumn{2}{|l|}{ Type of anesthesia } \\
\hline General & $16(41.0 \%)$ \\
\hline Regional & $23(59.0 \%)$ \\
\hline
\end{tabular}


In the group of patients using acetylsalicylic acid, 29.5\% did not know that they are using blood thinner drug, in the rivaroxaban group $34.1 \%$ did not know that they are using blood thinner drug and in the clopidogrel group, $43.2 \%$ did not know that they are using blood thinner drug (Table 3).

Table III: Frequency distribution of the blood thinner medications in the groups of the patients who are aware or unaware of the medications and in all cases

\begin{tabular}{|lcccccc|}
\hline & \multicolumn{2}{c}{$\begin{array}{c}\text { Aware } \\
(\mathbf{n = 1 2 6})\end{array}$} & \multicolumn{2}{c|}{$\begin{array}{c}\text { Unaware } \\
(\mathbf{n = 8 2})\end{array}$} & \multicolumn{2}{c|}{$\begin{array}{c}\text { All cases } \\
(\mathbf{n = 2 0 8})\end{array}$} \\
\cline { 2 - 7 } & $n$ & $\%$ & $n$ & $\%$ & $n$ & $\%$ \\
\hline Aspirin & 69 & 54.8 & 29 & 35.4 & 98 & 47.1 \\
\hline Rivaroxaban & 27 & 21.4 & 14 & 17.1 & 41 & 19.7 \\
\hline Clopidogrel & 21 & 16.7 & 16 & 19.5 & 37 & 17.8 \\
\hline Dabigatran & 14 & 11.1 & 13 & 15.9 & 27 & 13.0 \\
\hline Ticagrelor & 14 & 11.1 & 11 & 13.4 & 25 & 12.0 \\
\hline Apixaban & 3 & 2.4 & 8 & 9.8 & 11 & 5.3 \\
\hline Warfarin & 6 & 4.8 & 5 & 6.1 & 11 & 5.3 \\
\hline Dipyridamole & 2 & 1.6 & 1 & 1.2 & 3 & 1.4 \\
\hline
\end{tabular}

Distribution of males and females were similar between the groups that were aware of blood thinner medication use and that were not aware of blood thinner medication use $(p=0.497)$ (Table 4). Mean age was statistically significantly higher in the group that was unaware of blood thinner drug use compared to the group that was aware of drug use $(p=0.018)$ (Table 4). Level of education was statistically significantly lower in the group that was unaware of blood thinner drug use than the group aware of blood thinner drug use $(p<0.001)$. There is no difference between groups regarding to usage of novel AP or AC $(\mathrm{p}=0.113)$ (Table 4).
Table IV: Demographic and clinical characteristics of the patients who are aware or unaware of blood thinner drug use

\begin{tabular}{|lccc|}
\hline & $\begin{array}{c}\text { Aware } \\
\text { (n=126) }\end{array}$ & $\begin{array}{c}\text { Unaware } \\
\text { (n=82) }\end{array}$ & p-value \\
\hline Age (year) & $61.6 \pm 11.9$ & $65.9 \pm 13.5$ & $\mathbf{0 . 0 1 8} \dagger$ \\
\hline Gender & $66(52.4 \%)$ & $39(47.6 \%)$ & $0.497 \ddagger$ \\
\hline Male & $60(47.6 \%)$ & $43(52.4 \%)$ & \\
\hline Female & & & \\
\hline $\begin{array}{l}\text { Level } \\
\text { education }\end{array}$ & $31(24.6 \%)$ & $51(62.2 \%)$ & \\
\hline $\begin{array}{l}\text { Illiterate } \\
\text { Elementary } \\
\text { school }\end{array}$ & $73(57.9 \%)$ & $27(32.9 \%)$ & \\
\hline $\begin{array}{l}\text { High school or } \\
\text { above }\end{array}$ & $22(17.5 \%)$ & $4(4.9 \%)$ & \\
\hline $\begin{array}{l}\text { Use of novel AP } \\
\text { or AC }\end{array}$ & $55(43.7 \%)$ & $45(54.9 \%)$ & $0.113 \ddagger$ \\
\hline $\begin{array}{l}\text { Patients who } \\
\text { are using the } \\
\text { drug due to } \\
\text { stenting }\end{array}$ & & & \\
\hline $\begin{array}{l}\text { Aware of the } \\
\text { stent type }\end{array}$ & & & \\
\hline $\begin{array}{l}\text { Unaware of the } \\
\text { stent type }\end{array}$ & $30(73.2 \%)$ & $25(86.2 \%)$ & \\
\hline
\end{tabular}

† Student's t test, $\neq$ Pearson chi-square test

\section{DISCUSSION}

More than one-third of the patients who were evaluated pre-operatively were detected not to be aware of using AP and/or AC in our study evaluating 208 patients through a questionnaire form. Awareness was found to increase as age decreased and level of education increased. Additionally, $18.8 \%$ of the patients underwent a surgical procedure while using these drugs and regional anesthesia was the mostly preferred anesthesia method.

Having an operation while using AP and/or AC carries some risks such as major or minor bleeding, blood transfusion, hematoma 
formation and delayed wound healing, infections, longer duration of procedure and longer staying in hospital after operation. Conversely, cessation of AP and/or AC may cause atherotrombotic or thrombo-embolic events. In general, there is no need to interrupt $\mathrm{AP}$ and/or AC in low risk interventions such as cataract operation, endoscopy or colonoscopy without biopsy, superficial surgery or dental procedures $^{3}$. But for patients undergoing elective procedures with intermediate or high risk of bleeding and during which hemostatic control is essential such as vascular surgery, hip and spine surgery

epidural catheterization and intraperitoneal surgery, discontinuation of AP and/or AC is suggested $^{3}$. A decision to continue AP and/or AC should be individualized, with the risk weighed against the benefits of continuing therapy.

No routine laboratory test is available to indicate the effectiveness of acetylsalicylic acid, clopidogrel, prasugrel and ticagrelor. Acetylsalicylic acid which has been used for long years was found to be the mostly used AP and/or AC medication however novel drugs have begun to be used in recent years. Among them, ticagrelor and prasugrel are more potent than clopidogrel ${ }^{4,5}$. Anamnesis of the patient is of great importance at that point. The patient's being aware of his/her AP or AC and stating it would be helpful for prediction of postprocedural complications, particularly in urgent interventions. In our study, $39.4 \%$ of the patients were not aware of using AP and/or AC drugs.

Use of drug-coated stents is gradually increasing for revascularization of coronary arteries $^{6}$. Current guidelines recommend using dual AP therapy for one year without interruption 7,8 . In our study, $12.5 \%$ of the patients did not know since when they were using AP and/or AC drugs. Discontinuation of AP therapy in the early period and pro- thrombotic effect of the surgical procedure itself cause risk for stent thrombosis ${ }^{9-12}$. A high proportion of the patients (76.9\%) have stated that they were not informed about the total duration of drug use when starting therapy in our study. Approximately 5\% of the patients who were applied coronary artery stenting procedure undergo non-cardiac surgery during the first one year ${ }^{13-16}$. The patients who were diagnosed with acute coronary syndrome and who underwent drug-coated stenting procedure should be evaluated individually, a decision should be made considering AP-related hemorrhage risk and ischemia risk that could develop due to discontinuation of these drugs. In our study, drugs were detected to be started by cardiology clinic in the ratio of $70.2 \%$ and stenting procedure was found to be the most common cause, $78.6 \%$ of the patients who have stent were detected not to know their stent type. The surgeon, the anesthetist and the cardiologist should work in cooperation to evaluate these patients before operation ${ }^{13,17}$.

INR monitoring is obligatory in patients using warfarin and patients should be informed about importance of INR monitoring and potential complications of overdose warfarin such as bleeding ${ }^{18}$. While INR value could provide information about drug use and the level of anticoagulation in patients who are using warfarin, INR value cannot be used for this purpose in patients who are using new generation oral AC like dabigatran, rivaroxaban and apixaban ${ }^{19,20}$. In addition, routinely used tests like thrombin time, prothrombin time and activated partial thromboplastin time cannot be used for prediction of the level of coagulation as they are either very sensitive or very little sensitive for these drugs ${ }^{19}$. Moreover, antidotes of some novel oral anti-coagulants not being introduced into the market yet may challenge the management of urgent operations of the patients who are using these drugs. Whether these drugs have been used prior to the 
procedure and the time of taking the drug may reveal the need of antidote use or timing of the surgery.

AP and/or AC drugs should be questioned meticulously in preoperative period in patients who have diseases like coronary artery disease, cerebrovascular event, atrial fibrillation, cardiac valve replacement. Given that more than one-third of the patients are unaware of AP and/or AC medication use in our study, it becomes evident that the physicians who commence these medications should inform the patients more sufficiently.

Side effect of causing hemorrhage should be emphasized when commencing AP and/or AC medications and whether the patient has a disease which requires an elective or urgent operation should be questioned. A meticulous inquiry for an elective operation by the physician who would start the medication may lead to an alteration in the medication or the stent. In our study, $9.1 \%$ of the patients had an elective operation plan before commencement of the drug. The patients should certainly be informed about that they should alarm the surgeon when an operation comes into the foreground.

\section{CONCLUSION}

Patients may have to undergo an operation while using AP and/or AC. However, 39.4\% of these patients were detected not to be aware of the AP and /or AC that they were using. Meticulously history taking must be done especially in older patients with cardiovascular diseases for pre-operative evaluation.

Ethics Committee Approval: Two hundred and eight out of 210 patients who were using oral AP and/or AC and consulted to Department of Anesthesia and Reanimation for preoperative assessment between 1 June 2017 and 1 September 2017 were included in the study after ethics committee approval had been obtained from Mersin University and written informed consent had been obtained from the patients, 2 patients were excluded from the study although they had stated to use AP but they were not detected to use them.

Declaration of Conflicting Interests: The authors declare that they have no conflict of interest.

Financial Disclosure: No financial support was received.

\section{REFERENCES}

1. Murray CJ, Lopez AD. Alternative projections of mortality and disability by cause 1990-2020: Global Burden of Disease Study. Lancet. 1997; 349: 1498504.

2. Korte W, Cattaneo M, Chassot PG, et al. Perioperative management of antiplatelet therapy in patients with coronary artery disease. Thromb Haemost. 2011; 105: 743-9.

3. Kristensen SD, Knuuti J, Saraste A, et al. 2014 ESC/ESA Guidelines on non-cardiac surgery: cardiovascular assessment and management: The Joint Task Force on non-cardiac surgery: cardiovascular assessment and management of the European Society of Cardiology (ESC) and the European Society of Anaesthesiology (ESA). Eur Heart J. 2014; 35: 2383-431.

4. Wiviott SD, Braunwald E, Mc Cabe $\mathrm{CH}$, et al. Prasugrel versus clopidogrel in patients with acute coronary syndromes. N Engl J Med. 2007; 357: 200115.

5. Wallentin L, BeckerRC, Budaj A, et al. Ticagrelor versus clopidogrel in patients with acute coronary syndromes. N Engl J Med 2009; 361: 1045-57.

6. Head DE, Sebranek JJ, Zahed C, Coursin DB, Prielipp RC. A tale of two stents:perioperative management of patients with drug-eluting coronary stents. J Clin Anesth. 2007; 19: 386-96.

7. Windecker S, Kolh P, Alfonso F, et al. 2014 ESC/EACTS Guidelines on myocardial revascularization: The Task Force on Myocardial Revascularization of the European Society of Cardiology (ESC) and the European Association for Cardio Thoracic Surgery (EACTS) Developed with the special contribution of the European Association 
of Percutaneous Cardiovascular Interventions (EAPCI). Eur Heart J. 2014;35: 2541-619.

8. King SB, Smith SC Jr, Hirshfeld JW Jr, et al. 2007 Focused Update of the ACC/AHA/SCAI 2005 Guideline Update for Percutaneous Coronary Intervention. Circulation. 2008; 117: 261-95.

9. Iakovou I, Schmidt T, Bonizzoni E, et al. Incidence predictors, and outcome of thrombosis after successful implantation of drug-eluting stents. JAMA. 2005; 293: 2126-30.

10. Schouten 0, van Domburg RT, Bax JJ, et al. Non cardiac surgery after coronary stenting: early surgery and interruption of antiplatelet therapy are associated with an increase in major adverse cardiac events. J Am Coll Cardio. 2007; 49: 122-4.

11. Parolari A, Mussoni L, Frigerio M, et al. Increased prothrombotic state lasting as long as one month after on-pump and off-pump coronary surgery. J Thorac Cardiovasc Surg. 2005; 130: 303-8.

12. Lison S, Weiss G, Spannagl M, Heindl B. Postoperative changes in procoagulant factors after major surgery. Blood Coagul Fibrinolysis. 2011; 22: 190-6.

13. Savonitto S, Caracciolo M, Cattaneo M, DE Servi S. Management of patients with recently implanted coronary stents on dual antiplatelet therapy who need to undergo major surgery. J Thromb Haemost. 2011; 9: 2133-42.
14. Vicenzi MN, Meislitzer T, Heitzinger B, et al. Coronary artery stenting and non-cardiac surgery-a prospective outcome study. Br J Anaesth. 2006; 96: 686-93.

15. Berger PB, Kleiman NS, Pencina $M J$, et al. Frequency of major noncardiac surgery and subsequent adverse events in the year after drugeluting stent placement results from the EVENT (Evaluation of Drug-Eluting Stents and Ischemic Events) Registry. JACC Cardiovasc Interv. 2010; 3: 920-7.

16. To AC, Armstrong G, Zeng I, Webster MW. Noncardiac surgery and bleeding after percutaneous coronary intervention. Circ Cardiovasc Interv. 2009; 2: 213-21.

17. Brilakis ES, Banerjee S, Berger PB. Perioperative management of patients with coronary stents. J Am Coll Cardiol. 2007; 49: 2145-50.

18. Acar A, Hasbahçeci M, Başak F, et al. Bleedings caused by warfarin overdose. Dicle Med J. 2012; 39 : 223-6.

19. Favaloro EJ, Lippi G. The new oral anticoagulants and the future of haemostasis laboratory testing. Biochem Med. 2012; 22: 329-41.

20. Pinho-Gomes AC, Hague A, Ghosh J. Management of novel oral anticoagulants in emergency and trauma surgery. Surgeon. 2016; 14: 234-9. 